\title{
Nonverbal Communication for the Enhancement of Foreign Language Professional Competency in Medical Students: A Study
}

\author{
By Mária Bujalková* \\ Petra Zrníkovát
}

\begin{abstract}
Knowledge of nonverbal communication plays a significant role in the work of medical professionals enabling doctors to communicate with their patients and understand the signals which can be observed from their nonverbal behaviour. To optimize nonverbal communication of students, we use their presentations as activation forms in teaching the German language for specific purposes. Giving a talk is a good way for students to train for their future medical practice because it is one of the types of professional communication which represents synchronization of speech and nonverbal behaviour. Analysis of nonverbal communication showed that the students are not aware of the importance of the first impression. Moreover, their posture, gesture, keeping distance, facial expression and keeping eye-contact were all absent or used inappropriately. The reasons can be explained by the fact that the students do not link their verbal and nonverbal communication when used in the particular foreign language environment.
\end{abstract}

Keywords: Language for specific purposes, Nonverbal communication, Professional competence.

\section{Introduction}

In the scientific world, the field of nonverbal communication and research in this area of study has been known for several decades. This issue had been a part of the study of rhetoric as early as in ancient Greece. It dealt with the speaker's oral performance. However, there is no doubt that it pointed out the issue of nonverbal communication as well. Nonverbal communication was considered part of rhetoric until approximately the beginning of the $20^{\text {th }}$ century, excluding the generally-oriented work Chirologia: or The Natural Language of the Hand (1664) by John Bulwer or the important work The Expression of the Emotions in Man and Animals (1872) by Charles Darwin.

The issue of nonverbal communication gained intentional attention among scientists only in the second half of the $20^{\text {th }}$ century. Among the most prominent theorists of nonverbal communication of the human body is the American anthropologist Ray Birdwhistell, whose works Introduction to Kinesics (1952) and Kinesics and Context (1970) are still an essential source of information. Next, a significant work edited by R. Hinde called Non-Verbal Communication (1972) may also be mentioned. Another work titled Bodily

\footnotetext{
* Senior Lecturer, Head of Institute, Comenius University in Bratislava, Slovakia.

* Lecturer, Comenius University in Bratislava, Slovakia.
} 
Communication by Michael Argyle (1975) has also been often cited and further extended. Most of the research devoted to this issue has been conducted by Anglophone authors. It needs to be said that the rest of the world is lagging behind quite significantly.

There are several definitions of the term communication. Depending on the code selected, four types of communication can be distinguished (Tubbs and Moss 1991): a) Verbal/Vocal communication, i.e. communication through spoken words; b) Verbal/Non-vocal communication that occurs when words are involved but no speaking takes place (writing); c) Nonverbal/Vocal communication including sounds but not words; d) Nonverbal/Non-vocal communication containing non-vocal non-linguistic means. However, in Central Europe, the following simplified classification has been adopted: verbal communication, nonverbal communication, and para-verbal/ paralinguistic communication.

Nonverbal communication is not an independent field of study. Its concepts can be found in scientific disciplines such as biology, linguistics, psychology, anthropology or sociology. Moreover, in the list should be included their sub-disciplines, e.g. psycholinguistics, social psychology, sociolinguistics, cultural anthropology. The two authors offer the following simple definitions of the term nonverbal communication: "Nonverbal communication is a kind of communication using any means other than verbal signals" (Kováŕová 2009). "Nonverbal communication is a process in which people transmit and receive messages without using words" (Madonik 2001).

\section{Functions and Types of Nonverbal Communication}

\section{Functions of Nonverbal Communication}

According to Argyle (1988) there are five primary functions of nonverbal bodily behaviour in human communication:

- to express emotions,

- to express interpersonal attitudes,

- to accompany speech in managing the cues of interaction between speakers and listeners,

- self-presentation of one's personality,

- rituals (greetings).

\section{Types of Nonverbal Communication}

There are several types of nonverbal communication. According to $\mathrm{K}$. Cherry (2014), they are as follows:

\section{Facial expression}

Facial expressions are responsible for a huge proportion of nonverbal communication. Consider how much information can be conveyed with a smile or 
a frown. While nonverbal communication and behaviour can vary dramatically between cultures, the facial expressions for happiness, sadness, anger and fear are similar throughout the world.

\section{$\underline{\text { Gestures }}$}

Deliberate movements and signals are an important way to communicate meaning without words. Common gestures include waving, pointing, and using fingers to indicate numeric amounts. Other gestures are arbitrary and related to culture.

\section{Para-linguistics}

Para-linguistics refers to vocal communication that is separate from actual language. This includes factors such as tone of voice, loudness, inflection and pitch. Consider the powerful effect that tone of voice can have on the meaning of a sentence. When something is said in a strong tone of voice, listeners might interpret approval and enthusiasm. The same words said in a hesitant tone of voice might convey disapproval and a lack of interest.

\section{Body language and posture}

Posture and movement can also convey a great deal of information. While these nonverbal behaviours can indicate feelings and attitudes, research suggests that body language is far more subtle and less definitive that previously believed.

\section{$\underline{\text { Proxemics }}$}

People often refer to their need for "personal space", which is also an important type of nonverbal communication. The amount of distance we need and the amount of space we perceive as belonging to us, is influenced by a number of factors including social norms, situational factors, personality characteristics and level of familiarity. For example, the amount of personal space needed when having a casual conversation with another person usually varies between 18 inches to four feet. On the other hand, the personal distance needed when speaking to a crowd of people is around 10 to 12 feet.

\section{Eye Gaze}

Looking, staring and blinking can also be important nonverbal behaviour. When people encounter others or things that they like, their rate of blinking increases and their pupils dilate. Looking at another person can indicate a range of emotions, including hostility, interest and attraction.

\section{$\underline{\text { Haptics }}$}

Communicating through touch is another important nonverbal behaviour. There has been a substantial amount of research on the importance of touch in infancy and early childhood. Touch can be used to communicate affection, familiarity, sympathy and other emotions. 
Appearance

Our choice of colour, clothing, hairstyles and other factors affecting appearance are also considered a means of nonverbal communication. Research on colour psychology has demonstrated that different colours can evoke different moods. Appearance can also alter physiological reactions, judgments and interpretations. Subtle judgements can be made about someone based on his or her appearance. These first impressions are important, which is why experts suggest that job seekers dress appropriately for interviews with potential employers.

\section{Compliance of Verbal and Nonverbal Competencies}

The nonverbal communication topic often focuses on particular professions in which direct or indirect interaction among people takes place, including various occupations within the educational process. Knowledge of nonverbal communication is needed by people working in economics (business, marketing, and management of human sources) and mass media, and also plays a significant role in medicine. Compliance of verbal and nonverbal competencies in foreign languages is required at different levels from top managers or from participants of international scientific conferences (Dignen and Cracknell 2006). Their professionalism is demonstrated by their showing respect to nonverbal signals sent by other participants of the communication process (Hartley 2003).

The necessity to deal with compliance between verbal and nonverbal components of communication, which creates the basics of one's professional competency, is also confirmed by research. M. Weisbuch (with co-authors) states that nonverbal behaviour does not change in time and context in the studied group of communicants, whereas their verbal behaviour does. These authors have also found that it is more difficult for communicants to control their nonverbal behaviour as a whole, for example, their facial expression posture and distance, than to be aware of the content of their message transmitted verbally. Nonverbal behaviour requires not only sending isolated signals, but also coordinating different parts of the body at the same time. Parallel perception of verbal and nonverbal signals is very challenging, although very important because communication consists of one compact unit and not a separate linguistic and non-linguistic component (Weisbuch et al. 2010).

Critical thinking reflects the interplay of verbal and nonverbal communication as manifested in the model (Campbell and Fuller 2010) (Figure 1).

Sending positive signals to other communicants to gain their confidence and friendliness is a means, whereas the realization of a set communication plan is an objective (Weisbuch et al. 2010). Professional knowledge and skills itself are not enough. For this reason they should be accompanied by the implementation of special verbal and nonverbal competencies (Schulz von Thun 2005). When acquiring competencies in foreign languages, which will be applied in particular professional communication situations, it is essential to interpret nonverbal signs adequately within the target language community instead of within the native language community. Sometimes students can use 
language well, i.e. to form lexical, grammatical, syntactic and stylistic structures which are absolutely appropriate to a situation. On the other hand, it happens quite often that their foreign language competence is marked by traditions and meanings of nonverbal behaviour typical for their mother tongue. One way to prevent this is to provide training of professional nonverbal behaviour in foreign language teaching (Bergerová 2010).

Figure 1. Critical Thinking Diagram based on Truschel (2009), Paul and Elder (2008)

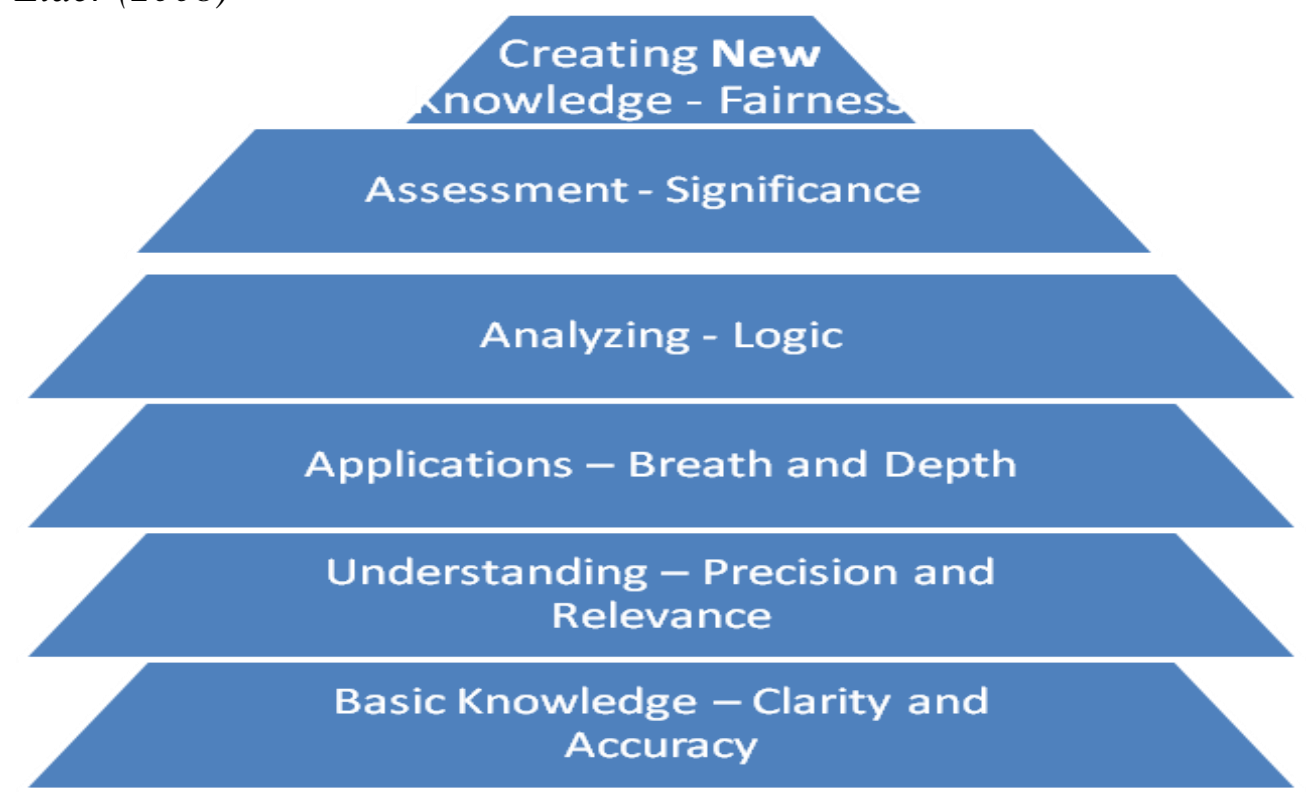

In the medical environment, compliance between verbal and nonverbal signals is one of the conditions for successful communication, i.e. clear and accurate exchanging and understanding messages in a doctor - patient relationship as well as between a doctor and a paramedic. When having knowledge of nonverbal communication principles, doctors can communicate better with each other, or with their patients, because they can read and understand their signals easily. Doctors' emotional behaviour and empathy, their ability to show understanding for their patients' feelings and actions, plays an unquestionable role in medicine.

\section{Enhancement of Foreign Language Professional Competency in Medicine}

At the Jessenius Faculty of Medicine in Martin (Comenius University, Slovakia) English and German language for specific purposes (ESP/GSP) is taught during two semesters for students of General Medicine and Dentistry. Students' language skills are generally $\mathrm{B} 2-\mathrm{C} 1$ on average according to the Common European Referential Framework for Languages. In this paper, it is German for professional purposes, which is going to be presented in more detail. 
During the GSP course, the students are taught not only language skills, but their attention is also focused on nonverbal communication. The goal is to enable students to acquire intercultural competencies and sensitivity to the traditions and habits of the other culture. In this way, the students practise textual and visual communication situations continually, mostly by means of a contrastive method. Course books by Ivanová and Hromadová (2010), Jarmuźek et al. (2003), and Schrimpf and Bahnemann (2012) are all used as well as Internet sources.

Effective communication requires deciphering the basic values, motives, aspirations, and assumptions that operate across geographical lines. Given that some dramatic differences exist across cultures in approaches to such areas as time, space, and privacy, the opportunities for miscommunication in crosscultural situations are plentiful (Wertheim 2012).

During the lessons of GSP, students are introduced to the particular, very specific intercultural differences, which are typical for a German GP's surgery and hospital environment. At the surgery in Germany (so called "Praxis") there works a specialized doctor's assistant officially known as "Medizinische Fachangestellte" (commonly called "Arzthelferin") who does not exist in the hierarchy of medical professions in Slovakia. They can perform their duties where necessary, e.g. in the consulting room, at the reception, ward rooms or in the laboratory. In short, such an assistant supports a practitioner in examination procedures and management work; the job can be described as complex which includes the duties of a laboratory technician, a secretary, a provider of technical support and a personal assistant - all in one person.

When meeting a patient in Germany, a doctor introduces himself and shakes a patient's hand, which is not common in Slovakia. Moreover, a patient is informed in detail about every step taken by the doctor during the examination process. A doctor does not enter notes into a computer while talking and explaining a diagnosis to a patient. He/she faces the patient and maintains eye contact with him/her instead. The medical report and other notes are summarized when the patient leaves the consulting room. To say goodbye, a doctor uses a phrase, for example: gute Besserung, alles Gute, einen schönen Tag noch, wir sehen uns am ..., etc., which is accompanied by a handshake again. "Typical" German features such as punctuality and timekeeping are obvious for both of them.

One of the activation forms for verbal and nonverbal communication being used in teaching the German language for specific purposes are scientific presentations (Bergerová 2007). The students at the medical faculty present and comment on topics of their choice individually (occasionally in pairs) and the texts cannot be taken from the textbook. The presentation is followed up by a discussion between the speaker and the audience taking place in the classroom. 


\section{Hypothesis}

One central assumption is based on these facts:

1. It is very important to understand that the majority of communication is nonverbal.

2. Nonverbal communication can play five roles:

- Repetition: it can repeat the message the person is making verbally.

- Contradiction: it can contradict a message the individual is trying to convey.

- Substitution: it can substitute for a verbal message.

- Complementing: it may add to or complement a verbal message.

- Accenting: it may accent or underline a verbal message (Wertheim 2012).

A presentation can be a very powerful supportive tool for developing competencies in foreign language teaching to medical students. The reasons for implementing a presentation in the educational process are as follows:

a) to increase students' motivation to obtain skills for using the target language actively because it is they who become the active part of the educational process;

b) by means of choosing the topic of a presentation, students can influence the content of the curriculum, and thus they can see whether their performance is informative and interesting enough;

c) it is one of the types of professional communication which represents synchronization of speech and nonverbal behaviour;

d) from the linguistic viewpoint the professional terminology and pronunciation, syntactic and grammatical structures, and idiomatic polite forms are being practiced during it the presentation;

e) in presentations, many features of nonverbal communication are being simulated which doctors will later use in the consulting room, at conferences or at hospital in a German-speaking environment;

f) it serves as a tool to acquire the patterns and rules applied in professional nonverbal behaviour, which are closely connected to the language forms of the target language;

g) it allows intentional use of para-lingual means, such as intonation, stress and emphasis for key information, with pauses giving time to listeners to make connections and follow the context, speech rate etc.;

h) it provides students with knowledge that their nonverbal communication is strongly recognized by the others, and thus it plays a significant role in their future professional communication.

In our paper we work on the assumption that future doctors will face medically-oriented situations and attitudes which will be manifested verbally and nonverbally by speakers in the target language communication: 


\section{Presentation of a scientific topic}

This is a situation which doctors will experience at congresses, conferences or workshops several times during their professional career. They are required to present the results of their research and defend and compare them to the other relevant sources and express their viewpoint on the issues discussed and the opinions proposed by others. During the presentation they will use a wide range of nonverbal signs; beginning with appearance, posture, keeping eye contact, gestures up to facial expression, inflection, intonation, and speech rate.

\section{Asking and answering questions}

Asking and answering questions between a doctor and a patient is a daily process when taking medical history to make a diagnosis, informing a patient, or as part of a pre-operative examination. Besides patient-friendly behaviour and empathy, the doctor's ethical acts (for example, which approach to choose when informing a patient about a serious, fatal disease) are also assigned a crucial role. An appropriate facial expression, friendly and helpful gestures, tone of voice and physical contact appropriate to the situation are all examples of nonverbal manifestations in communication situations like this.

\section{$\underline{\text { Discussion }}$}

Discussion and dialogue between medical professionals result in exchange of experience, opinions and outcomes of their work in the field of conservative and surgical therapy, research, new methods in medicine and pharmacotherapy, consultations about a patient's condition etc. A doctor takes part in the discussion in order to share his opinion on the issue, his belief that he is right, to agree or disagree with his colleagues. Of course, these manifestations are accompanied by nonverbal signals including gestures, body posture, eye contact, volume of speech, and respect to physical distance etc.

\section{Evaluation}

In medical practice the evaluation process is present, for example, when assessing a patient's condition, following a course of therapeutic or surgical treatment, or when considering a medical procedure and the approach of a particular doctor, his professional knowledge and the range of total health care provided. Showing tactful manners, respect to interpersonal relationships as well as friendly nonverbal signs is very important in these situations. The posture, facial expression, haptics, eye contact and intonation may influence the communication act significantly if they follow the context. Intercultural differences should be taken into consideration.

\section{Methodology}

A selected sample of the experimental study was made up of 250 students of medicine who had chosen a German language course. The data had been collected and evaluated over a period of 10 years (academic years 2003/20042013/2014). Criteria for assessing a presentation as a whole are based on "The 
Framework for Teaching German at Universities in the Czech and Slovak Republic" (Beníšková-Schulze et al. 2000/2002):

\begin{tabular}{|l|l|}
\hline $\begin{array}{l}\text { INHALT } \\
\text { Contents }\end{array}$ & $\begin{array}{l}\text { Auswahl des Themas, Länge der Präsentation } \\
\text { topic selection, length of presentation }\end{array}$ \\
\hline $\begin{array}{l}\text { STRUKTUR } \\
\text { Structure }\end{array}$ & $\begin{array}{l}\text { Klarheit, Kohärenz } \\
\text { clarity, coherence }\end{array}$ \\
\hline $\begin{array}{l}\text { SPRACHE } \\
\text { Language }\end{array}$ & $\begin{array}{l}\text { sprachliche Richtigkeit, Flüssigkeit, Aussprache, Intonation, } \\
\text { Sprechtempo } \\
\text { linguistic accuracy, fluency, pronunciation, intonation, pace }\end{array}$ \\
\hline $\begin{array}{l}\text { UNVERBALE } \\
\text { ASPEKTE } \\
\text { Nonverbal aspects }\end{array}$ & $\begin{array}{l}\text { Gestik, Augenkontakt, Körpersprache, Selbstsicherheit } \\
\text { gestures, eye contact, body language, self-confidence }\end{array}$ \\
\hline $\begin{array}{l}\text { VISUELLE } \\
\text { UNTERSTÜTZUNG } \\
\text { Visual support }\end{array}$ & passend, klar, geschickt angewendet \\
balanced, clear, used appropriately
\end{tabular}

The goal of the research was to evaluate the criteria of nonverbal aspects in each presentation. We used a set of questions which helped to define particular nonverbal signals:

\begin{tabular}{|l|l|}
\hline Eye contact & Is eye contact being made? If so, is it overly intense or just right? \\
\hline $\begin{array}{l}\text { Facial } \\
\text { expression }\end{array}$ & $\begin{array}{l}\text { What is her/his face showing? Is it mask-like and inexpressive, or } \\
\text { emotionally present and filled with interest? }\end{array}$ \\
\hline Tone of voice & $\begin{array}{l}\text { Does her/his voice project warmth, confidence, and interest, or is it } \\
\text { strained and/or impassive? }\end{array}$ \\
\hline $\begin{array}{l}\text { Posture and } \\
\text { gesture }\end{array}$ & $\begin{array}{l}\text { Is her/his body relaxed or stiff and immobile? Are shoulders tense } \\
\text { and raised, or slightly sloped? }\end{array}$ \\
\hline Touch & Is there any physical contact? Is it appropriate to the situation? \\
\hline Intensity & $\begin{array}{l}\text { Does the presenter seem flat, cool, and disinterested, or over-the-top } \\
\text { and melodramatic? }\end{array}$ \\
\hline $\begin{array}{l}\text { Timing and } \\
\text { pace }\end{array}$ & $\begin{array}{l}\text { Is there an easy flow of information back and forth? Do nonverbal } \\
\text { responses come too quickly or too slowly? }\end{array}$ \\
\hline Sounds & Do you hear sounds that indicate caring or concern? \\
\hline
\end{tabular}

Source: Segal et al. 2015.

\section{Students' Feedback}

In line with the latest didactic principles, we find it important to keep the content and methods of teaching tailor-made to students' individual as well as professional needs. The students actively participate in the didactic process, i.e. can influence the content of the curriculum and freely express their opinions about the content and teaching methods. 


\section{Evaluating Presentations and Nonverbal Signals}

In this section we provide examples of topics chosen by students according to their choice. The students usually present the following topics in:

- Clinical medicine: Adipositas, Diabetes mellitus, Schwangerschaft, Wirkungen und Metabolismus von Alkohol, Human Papillomavirus, Die tropischen Krankheiten, Anorexia nervosa, Down Syndrom, Der plötzliche Kindstod, Alkoholembryopathie, Stress - Freund oder Feind, Vogelgrippe, Ebola-Fieber, Drogenabhängigkeit, Multiple Sklerose, Plötzlicher Herztod beim Sport, Mammaplastik, Morbus Parkinson, Schlaganfall, Syndrom ADHD, Zahnkaries;

- History of medicine: Medizin im antiken Griechenland, Johannes Jessenius, Äskulapstab vs. Hermesstab, Erste Herztransplantation;

- Medicine-related issues: Sterbehilfe, Kontakt mit den Autisten, Homöopathie, Freie Radikale, Familienberatung, Tee und Gesundheit, Heilhypnose, Schlafhygiene, Bionik \& Kybernetik, Das Rote Kreuz, Operationssaal, etc.

As mentioned above, the students become familiar with intercultural competencies and the role of nonverbal behaviour when speaking German throughout the course. The importance of these features of communication is emphasized in terms of their future career. For example, the students focus only on the speaker's nonverbal behaviour when they try to evaluate presentations by means of asking questions.

We strongly believe that it is important to discuss and evaluate each presentation (10-15 minutes long) with the whole class according to the selected criteria given in the table above. At the beginning, the students usually refuse to "criticize" one another. After explanation that the goal is not to criticize, but rather to learn from each other and share suggestions for improving performance which can help all of them, they become more willing to offer feedback. This is given by students in a relaxed atmosphere, in part as a result of the presentations not being graded.

Of course, the teacher also participates in the process of evaluation; she/he comments on keeping balance between verbal and nonverbal performance throughout the presentation. The teacher points out the strengths and weaknesses of the overall structure as well as any particularly serious mistakes (grammar, lexical, syntactic and stylistic) made. Last but not least, the amount of text in particular slides is also a signal of the level of presentation competencies acquired. Slides with too much data, with whole sentences and compound clauses, occurred very frequently. This appears to be an effort on the part of the presenter to avoid independent commenting on keywords in the foreign language.

The following shortcomings in nonverbal behaviour were often noticed during students' presentations (Figure 2): 
- A lack of self-confidence manifested by over-reliance notes.

- Intonation and pauses inappropriate to the content and structure of the speech.

- Inadequate speech pace, gestures and posture.

- A recurrent failure to maintain eye contact with the audience.

- Constant focus on notes or elsewhere, even when presenters were talking by heart.

- Students did not like to stand while giving a talk; they tried to make a barrier using the computer.

- Various nonverbal gestures, smiles and/or a friendly atmosphere were missing.

In the final discussion to the presentation:

- Emphasising the verbal message by appropriate and adequate nonverbal behaviour, such as intonation, haptics or eye contact was omitted.

- The students stared at the floor or looked beyond or "through" the other communicant.

- Many of them were overly focused on the teacher, probably in their need to reassure themselves that the teacher agreed with the phrase chosen.

Figure 2. Graph Showing the Most Frequent Shortcomings in Nonverbal Communication

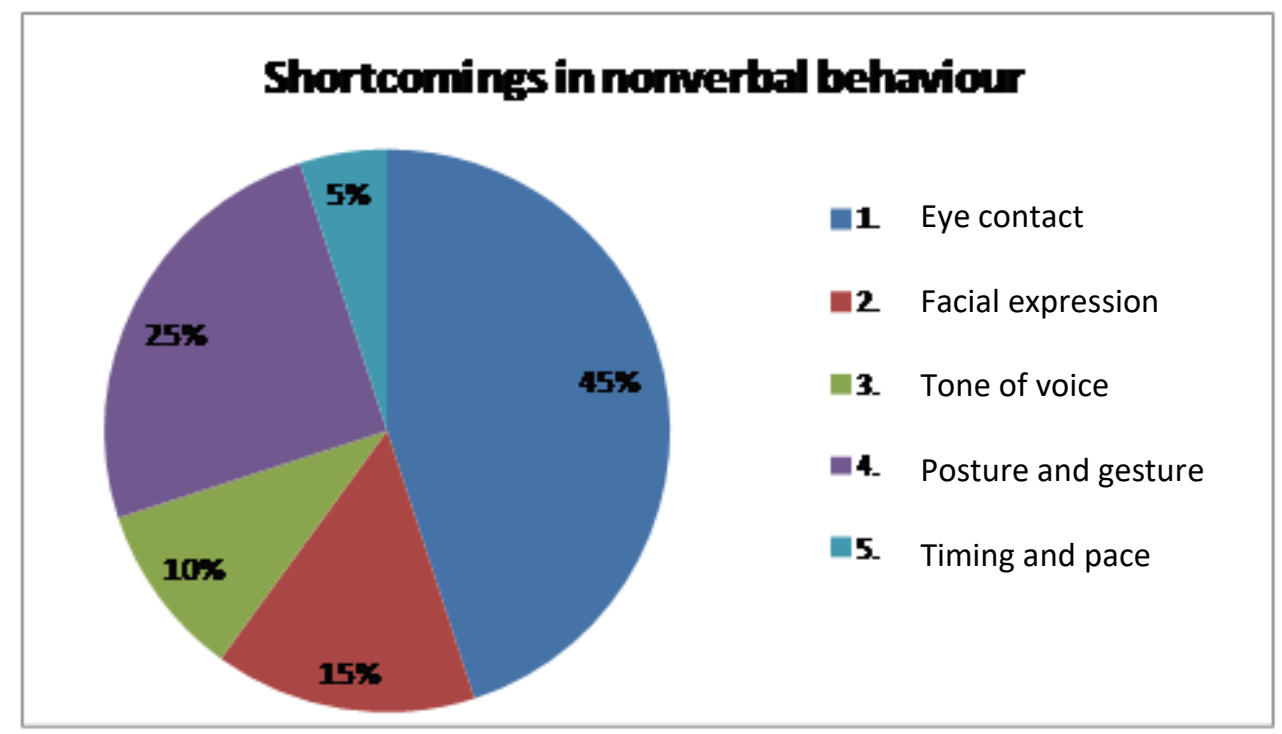

\section{Discussion}

In general, in Slovakia students are not well educated in the principles of nonverbal behaviour. At secondary schools they are not able to present the topic of their choice adequately even in their mother tongue, not to mention in German. In this respect, we did not have great expectations from our medical students. Nonverbal communication in their assessment represents a basic 
requirement ensuring development of their professional foreign language competence. This is one of our aims when teaching GSP. It can be concluded that our concerns have been confirmed. The students do not always realize the importance of the first impression.

Despite the fact that the Slovak and German cultural environment do not widely differ from each other, our students were unfortunately unable to handle elementary principles of nonverbal communication (which are the same for both countries) at the level required. Also, the students do not always realize the importance of the first impression.

The analysis revealed that students are not aware of the importance of their nonverbal behaviour when expressing their attitudes (in foreign language speaking) in particular communication situations. Their skills improved partially after intentional training in professional situations by means of students' presentations during the GSP course. This enabled them to realize how significantly nonverbal communication can influence and support their professional competencies.

In our opinion, the current unfavourable state is caused by inadequate training in the mother tongue, in which students are also unable to control and interpret nonverbal signals consciously. Another aspect increasing the risk of incompliance between verbal and nonverbal component of communication is the presupposition that a perfect graphic-visual layout of a presentation is enough to make a good overall impression on the audience and teacher. Unfortunately, this often dominates over the oral performance and thus leaves a rather poor impression on the audience.

\section{Conclusion}

Acquiring compliance between the verbal and nonverbal component of communication is a long-term goal which has been set in language teaching for our medical students. The communicative approach in teaching German language for professional purposes allows us to show the students that their participation in language education is meaningful and useful for their practice. They will understand that nonverbal training enhances their communication competency, which can be applied in German speaking as well as in the mother tongue environment.

Our long-term experience has shown that students do not pay adequate attention to the meaning of nonverbal communication. In language communication, simultaneous receiving of verbal and nonverbal signals is very important because together they represent one well-integrated whole, instead of discrete verbal and nonverbal components. Therefore, we consider it essential to include training of professional nonverbal behaviour in foreign language teaching. 


\section{Acknowledgments}

The paper was supported by the project "Virtual and Simulation Tuition as a New Form of Education at JFM CU in Martin". The project is in the "Modern education for the knowledge-based society" category and has been co-financed by European Union resources.

\section{References}

Argyle M (1975) Bodily Communication. London: Methuen.

Argyle M (1988) Bodily Communication (2nd Ed.). Madison: International Universities Press.

Beníšková-Schulze B, Bujalková M, Drnková L, Janíková M, Klápštová K, Kölmel B, Kubíčková $\mathrm{F}$, Kuželová $\mathrm{V}$, Motešická Z, Odstrčilová M, Peřinová N, Podhorná L, Rošková A, Smerigová E, Trošoková L, Vlčková I, Záhorcová J, Zavatčanová M (2000/2002) Rahmencurriculum des studienbegleitenden Deutschunterrichts an tschechischen und slowakischen Hochschulen und Universitäten (Curriculum of the Course-Teaching German at Czech and Slovak Colleges and Universities). Bratislava, Fraus, Pilsen: Goethe-Institut.

Bergerová R (2007) Studentské prezentace - jedna z aktivizačných forem cizojazyčné výuky (Student presentations - One of the Activating Forms of Foreign Language Teaching). Cizí jazyky 51: 133-135.

Bergerová R (2010) Neverbální komunikace a vysokoškolská výuka cizojazyčné profesní kompetence (Nonverbal Communication and Academic Foreign Language Teaching Professional Competence). Cizí jazyky 54: 4-8.

Birdwhistell RL (1952) Introduction to Kinesics: An Annotation System for Analysis of Body Motion and Gesture. Washington, DC: Department of State, Foreign Service Institute.

Birdwhistell RL (1970) Kinesics and Context: Essays on Body Motion Communication. Philadelphia: University of Pennsylvania Press.

Bulwer J (1644) Chirologia: or the naturall language of the hand. London: Thomas Harper.

Campbell B, Fuller T (2010) Tutor Training. Nonverbal Tutoring. Retrieved from: http://goo.gl/E3beHR. [Accessed: January 2015]

Cherry K (2014) Types of Non-verbal Communication. Retrieved from: http://goo.gl/hqvne. [Accessed: 10 June 2014]

Darwin CR (1872) The Expression of the Emotions in Man and Animals. London: John Murray.

Dignen B, Cracknell B (2006) Managing People Across Cultures. In R. Turner (Eds.), Proceedings of 20th IPMA World Congress on Project Management 1-2: 765-768.

Hartley M (2003) Body Language at Work. London: Sheldon Press.

Hinde RA (1972) Non-Verbal Communication. Cambridge: Cambridge University Press.

Ivanová A, Hromadová K (2010) Deutsch für medizinische Berufe (German for Medical Professions). Bratislava: Univerzita Komenského.

Jarmuźek E, Król E, Malinow A, Piosik MT, Rozwalka J, Tworek U, Lévy-Hillerich D (2003) Kommunikation in sozialen und medizinischen Berufen (Communication in Social and Health Professions). Fraus, Pilsen, München: Goethe-Institut. 
Kovářová D (2009) Teorie neverbální komunikace a edukační proces (Theory Nonverbal Communication and Educational Process). Cizí jazyky 53: 39-42.

Madonik BC (2001) I Hear What You Say, But What Are You Telling Me? The Strategic Use of Nonverbal Communication in Mediation. San Francisco: JoseyBass (Wiley).

Schrimpf U, Bahnemann M (2012) Deutsch für Ärztinnen und Ärzte. Kommunikationstraining für Klinik und Praxis (German for Doctors. Communication Training for Clinical Medicine and Practice). Berlin, Heidelberg: Springer.

Schulz von Thun F (2005) Jak spolu komunikujeme (As we Communicate). Praha: Grada.

Segal J, Smith M, Boose G, Jaffe J (2015) Nonverbal Communication. Improving Your Nonverbal Skills and Reading Body Language. Retrieved from: http://goo.gl/DYbrF. [Accessed: February 2015]

Tubbs S, Moss S (1991) Human Communication. USA: McGraw-Hill.

Weisbuch M, Slepian ML, Clarke A, Ambady N, Welle JV (2010) Behavioral Stability Across Time and Situations: Nonverbal Versus Verbal Consistency. Journal of Nonverbal Behaviour 34: 43-56.

Wertheim EG (2012) The Importance of Effective Communication. Retrieved from: https://goo.gl/9HgkFJ. 